\title{
Re-evaluation of the characters used to distinguish Enteropogon from Chloris (Poaceae)
}

\author{
S.W.L. Jacobs and J. Highet
}

\begin{abstract}
Jacobs, S.W.L., and Highet, J. (National Herbarium of New South Wales, Royal Botanic Gardens, Sydney, Australia 2000) 1988. Re-evaluation of the characters used to distinguish Enteropogon from Chloris (Poaceae). Telopea 3(2): 217-221. - We examined the six characters that have been used to distinguish the genera Enteropogon and Chloris. Only two (fertile floret compression and relative embryo length) proved to be of any taxonomic value. Despite this reduction in the number of distinguishing characters we decided that there is an argument for maintaining the use of Enteropogon in Australia.
\end{abstract}

\section{Introduction}

The genus Enteropogon was established by Nees (Lindley 1836). It was not made clear how this genus was to be distinguished from Chloris as the original description contains comparisons only with Dinebra (as Dineba) and Heterosteca (as Heterostega). Clayton (1967), in reviewing a group of genera including Enteropogon, commented that the distinction between Chloris and Enteropogon had usually been based on inflorescence form, that of species of Enteropogon being a solitary spike. He cast doubt on the possession of a solitary spike as the delimiting character by adding to Enteropogon a species that frequently had two or three spikes. In that paper, where he discussed the problem of distinguishing satellite genera from large polymorphic genera, Clayton suggested the use of the compression of the fertile floret as a character with potential for distinguishing Enteropogon (dorsally compressed) from Chloris (laterally compressed).

Lazarides (1972) expanded the concept of Enteropogon by delimiting the genus on the dorsal compression of the fertile floret. He dismissed inflorescence form as a delimiting character for the genus, elaborated on the compression character by including a description of the caryopses and added two further characters: (i) the length of the embryo relative to the caryopsis, and (ii) the development of the second floret. Enteropogon was characterised by him as having an embryo no more than one third the length of the caryopsis and a poorly developed upper floret. Chloris was characterised by having an embryo one half to two thirds the caryopsis length and '... a usually well-developed second floret or lemma'.

Anderson (1974) followed Lazarides in the broader treatment of Enteropogon, adding another character by contrasting the simple angular starch grains of Enteropogon with the exclusively compound grains of Chloris. Anderson extracted his data about this character from a paper by Tateoka (1962) even though Tateoka had concluded that some of the reported differences (those repeated by Anderson) were not taxonomically significant.

Clayton (1982) took up the circumscription used by Lazarides (1972) and Anderson (1974) and implied a further character, 'long drooping racemes', to 
help delimit Enteropogon. This addition was ascribed to Lazarides (1972) but that author did not mention this character.

Although some Australian species have been placed in the genus Enteropogon (Simon 1984) several authors have either not accepted this (Jacobs \& Pickard 1981; Wheeler, Jacobs \& Norton 1982; Beadle, Evans \& Carolin 1982) or accepted it with apparent reservation (Tothill \& Hacker 1983). This hesitancy has been due, at least partly, to some dissatisfaction with the documentation of the characters and some doubt as to the accuracy and/or taxonomic reliability of the characters cited. The characters that have been used to distinguish the two genera break down most commonly in the Australian species. Understanding the character variation in the Australian species is critical for assessing the status of Enteropogon.

We decided that the most appropriate action was to examine the characters used to substantiate the maintenance of Enteropogon as a separate genus and to measure their variability in the Australian species and hence assess the taxonomic value of the characters.

\section{Methods}

Thirty specimens representing seven species of Enteropogon and three species of Chloris were compared; all were species native to Australia. Details of voucher specimens are available from the authors; all specimens are held at NSW.

As many of the following characters as possible (e.g. not all inflorescences contained caryopses) were recorded from each of ten inflorescences for each species:

(i) spike number (Clayton 1967)

(ii) spike rigidity (Clayton 1982)

(iii) fertile floret compression (Lazarides 1972)

(iv) embryo length relative to the caryopsis (Lazarides 1972)

(v) starch grain shape (Anderson 1974), and

(vi) development of the second floret (Lazarides 1972).

Observations of most of these characters required no special preparation of material. Starch grain type was assessed by soaking seeds in warm water for a few hours, squashing the seeds on microscope slides in water-soluble mounting medium and examining the slides under the light microscope.

\section{Results and discussion}

The results recorded (Table 1) are those observed on the specimens used and in no way are meant to describe the total range of variation of any character for any taxon.

(i) Spike number. This character has already been discussed by most authors and the results here reinforce that.

(ii) Spike rigidity. A character used by Clayton (1982) without explanation. It has no validity as a delimiting character as both states occur in each genus. 
Table 1. Comparison of characters used to separate the genera Enteropogon and Chloris

\begin{tabular}{|c|c|c|c|c|c|c|}
\hline $\begin{array}{l}\text { Species } \\
\mathrm{E}=\text { Enteropogon } \\
\mathrm{C}=\text { Chloris }\end{array}$ & $\begin{array}{l}\text { Spike } \\
\text { number }\end{array}$ & $\begin{array}{l}\text { Spike } \\
\text { rigidity }\end{array}$ & $\begin{array}{l}\text { Floret } \\
\text { compression }\end{array}$ & $\begin{array}{l}\text { Embryo } \\
\text { length } \\
\text { relative to } \\
\text { caryopsis } \\
\% \text { (range) } \\
\mathrm{n}=\text { sample } \\
\text { size }\end{array}$ & $\begin{array}{l}\text { Starch } \\
\text { grain } \\
\text { shape }\end{array}$ & $\begin{array}{l}\text { Relative } \\
\text { development } \\
\text { of second } \\
\text { floret }\end{array}$ \\
\hline E. dolichostachyus & $5-6$ & drooping & dorsal & $\begin{array}{l}25(22-30) \\
n=12\end{array}$ & $\begin{array}{l}\text { simple, } \\
\text { rounded + } \\
\text { angular }\end{array}$ & $\begin{array}{l}\text { infertile, } \\
\text { smaller }\end{array}$ \\
\hline E. acicularis & $13-15$ & rigid & dorsal & $\begin{array}{l}29(22-34) \\
n=12\end{array}$ & $\begin{array}{l}\text { simple, } \\
\text { angular }+ \\
\text { a few } \\
\text { rounded }\end{array}$ & $\begin{array}{l}\text { infertile, } \\
\text { smaller }\end{array}$ \\
\hline $\begin{array}{l}\text { E. sp. (S. Jacobs } \\
1571)\end{array}$ & $2(-3)$ & drooping & dorsal & $\begin{array}{l}29(24-32) \\
n=4\end{array}$ & $\begin{array}{l}\text { simple, } \\
\text { angular }+ \\
\text { a few } \\
\text { rounded }\end{array}$ & $\begin{array}{l}\text { infertile, } \\
\text { smaller }\end{array}$ \\
\hline E. ramosus & $3-4$ & rigid & dorsal & $\begin{array}{l}33(30-38) \\
\mathrm{n}=11\end{array}$ & $\begin{array}{l}\text { simple, } \\
\text { angular }+ \\
\text { a few } \\
\text { rounded }\end{array}$ & $\begin{array}{l} \pm \text { fertile } \\
\text { smaller }\end{array}$ \\
\hline E. paucispiceus & $1-2$ & drooping & dorsal & $\begin{array}{l}35(29-42) \\
n=4\end{array}$ & $\begin{array}{l}\text { simple, } \\
\text { angular }+ \\
\text { a few } \\
\text { rounded }\end{array}$ & $\begin{array}{l}\text { infertile, } \\
\text { much } \\
\text { smaller }\end{array}$ \\
\hline E. minutus & $2-4$ & drooping & dorsal & $\begin{array}{l}37(32-40) \\
n=8\end{array}$ & $\begin{array}{l}\text { simple, } \\
\text { angular }+ \\
\text { a few } \\
\text { rounded }\end{array}$ & $\begin{array}{l}\text { infertile, } \\
\text { smaller }\end{array}$ \\
\hline E. unispicea & 1 & drooping & dorsal & $\begin{array}{l}37(35-39) \\
\mathrm{n}=3\end{array}$ & $\begin{array}{l}\text { simple, } \\
\text { rounded }+ \\
\text { a few } \\
\text { angular }\end{array}$ & $\begin{array}{l}\text { infertile, } \\
\text { much } \\
\text { smaller }\end{array}$ \\
\hline $\begin{array}{l}\text { C. divaricata var. } \\
\text { divaricata }\end{array}$ & 46 & rigid & lateral & $\begin{array}{l}42(33-55) \\
\mathrm{n}=9\end{array}$ & $\begin{array}{l}\text { simple, } \\
\text { angular }+ \\
\text { a few } \\
\text { compound }\end{array}$ & $\begin{array}{l}\text { infertile, } \\
\text { smaller }\end{array}$ \\
\hline $\begin{array}{l}\text { C. divaricata var. } \\
\text { cynodontoides }\end{array}$ & $5-6$ & rigid & lateral & $\begin{array}{l}46(42-54) \\
n=10\end{array}$ & $\begin{array}{l}\text { simple, } \\
\text { angular }+ \\
\text { a few } \\
\text { compound }\end{array}$ & $\begin{array}{l}\text { infertile, } \\
\text { smaller }\end{array}$ \\
\hline C. ventricosa & $2-4$ & drooping & lateral & $\begin{array}{l}49(38-57) \\
n=9\end{array}$ & $\begin{array}{l}\text { simple, } \\
\text { angular }\end{array}$ & $\begin{array}{l}\text { infertile, } \\
\text { smaller }\end{array}$ \\
\hline C. truncata & $7-9$ & rigid & lateral & $\begin{array}{l}50(44-56) \\
\mathrm{n}=9\end{array}$ & $\begin{array}{l}\text { simple, } \\
\text { angular }\end{array}$ & $\begin{array}{l}\text { infertile, } \\
\text { smaller }\end{array}$ \\
\hline
\end{tabular}

(iii) Fertile floret compression. As indicated by Lazarides (1972) this character does indeed distinguish the two genera. It can be difficult to assess as an immature floret from a species of Enteropogon may look very similar to a floret from a species of Chloris. In the Australian species at least, the distinction is best observed by examining the caryopses (Lazarides 1972). The caryopsis is quite distinctly dorsally flattened with a shallow ventral groove in species of Enteropogon, whereas in the species of Chloris examined there may still be a shallow ventral groove but the caryopsis is triangular in trans-section. 
(iv) Embryo length relative to caryopsis. This character does indicate a distinction when the mean is considered but the difference is not statistically significant when the variation in each species and the small number of Chloris species examined are considered. Although the means are not distinct, when the species are ordered on the embryo length (Table 1) there is an obvious trend in this non-dependent character to larger embryos in Chloris and smaller in Enteropogon. There is no clear break in the figures and individuals do overlap. Nonetheless the trend does support the distinction based on spikelet compression.

(v) Starch grain shape. We found no clear distinction between those species with simple angular starch grains and those with compound grains. Often both were present in one seed, as well as within one species. Distinctions based on this character may reflect inadequate sampling rather than a real difference.

(vi) Development of the second floret. This is a subjective character and one that we were not able in any way to correlate with the distinction based on the compression of the fertile floret. The second floret was infertile and much reduced in all of the material examined, except in one specimen of E. ramosus, which produced a mature, but small, caryopsis in the second floret.

Of the six characters used by various authors to delimit the genera Enteropogon and Chloris, four (i, ii, v and vi) are quite useless, one (fertile floret compression) seems reliable, and another (embryo length), while not discontinuous enough to be of practical value in distinguishing the genera, shows a trend that supports the division based on compression of the fertile floret.

\section{Conclusions}

This reduction in the number of diagnostic characters does cast some doubt on the value of recognising Enteropogon as a genus distinct from Chloris. The remaining characters, fertile floret compression (best determined from the shape of the mature caryopsis) and the trend in Enteropogon to shorter embryos relative to the length of the mature caryopsis, are probably adequate, following the philosophy expressed by Clayton (1967) on the separation of satellite genera from large polymorphic genera, to maintain a distinction between Enteropogon and Chloris in Australia.

\section{Acknowledgements}

We thank Joy Everett for her helpful comments on the manuscript.

\section{References}

Anderson, D.E. (1974) Taxonomy of the genus Chloris (Gramineae). Brigham Young Univ. Sci. Bull. Biol. Series 19(2): 1-133.

Beadle, N.C.W., Evans, O.D., \& Carolin, R.C. (1982) 'Flora of the Sydney Region'. Edn 3 (A.H. \& A.W. Reed: Sydney).

Clayton, W.D. (1967) Studies in the Gramineae XIII. Kew Bull. 21: 99-110.

Clayton, W.D. (1982) Notes on subfamily Chloridoideae (Gramineae). Kew Bull. 37: $417-420$.

Jacobs, S.W.L., \& Pickard, J. (1981) 'Plants of New South Wales' (Govt Printer: Sydney). 
Lazarides, M. (1972) A revision of Australian Chlorideae (Gramineae). Austral. J. Bot., Suppl. Series No. 5: 1-51.

Lindley, J. (1836) 'Natural System of Botany'. Edn 2 (Longman: London).

Simon, B.K. (1984) Two new species of Enteropogon (Poaceae: Chlorideae) in Australia. Austrobaileya 2(1): 1-6.

Tateoka, T. (1962) Starch grains of endosperm in grass systematics. Bot. Mag. (Tokyo) $75(892): 377-383$.

Tothill, J.C., \& Hacker, J.B. (1983) 'The Grasses of southern Queensland' (Univ. Queensland Press: Brisbane).

Wheeler, D.J., Jacobs, S.W.L., \& Norton, B.E. (1982) 'Grasses of New South Wales' (Univ. New England Press: Armidale).

Manuscript received 18 April 1985

Manuscript accepted 19 June 1987 